\title{
Related Loan on Real Estate Firm Performance in an Emerging Market
}

\author{
Purwanto PURWANTO ${ }^{1}$
}

Received: August 01, 2020 Revised: September 06, 2020 Accepted: September 10, 2020

\begin{abstract}
This study investigates the relationship between related loan, ownership concentration and real estate firm performance. The data was collected from 35 real estate firms listed on Indonesia Stock Exchange from 2007 to 2012. Related loans are viewed from the angle of related lending and loan. Related lending and loan is measured by the related lending on total lending ratio and related loan on total loan ratio. Firm performance is measured by the asset turnover ratio and return on assets ratio. Ownership concentration is measured by the right cash flow. The data analysis was done with regression analysis and panel data. The results of the study found that related loans had a positive effect on sales but had no effect on profits. This supports the efficient transaction hypothesis. On the other hand, related lending has a positive effect on profits that supports opportunistic transactions. Ownership concentration moderates the effect of related loan on company's performance. The related lending are beneficial for mutually supporting activities in the real estate sector business group in Indonesia, but related loans have the potential to be used in tunneling activities. The paper contributes to the related party transaction in benefits-risks of related lending and related loan in uncertainty context.
\end{abstract}

Keywords: Related Loans, Efficient Transaction, Opportunity Transaction

JEL Classification Code: G32, G31, G38

\section{Introduction}

Real estate sector plays an important role in economy to the extent of activities related to consumption, investment, and speculation. Related to consumption, the real estate sector offers infrastructure to be used for residential and commercial activities. The sector is also related to investment activities, be it the primary or secondary markets, which supports the economic growth. Ownership of land and buildings for real estate can be exploited for investment activities which at the same time can be used for consumption of goods with slow market adjustment process (O'Sullivan \& Gibb, 2003). Not only it is used for consumption and investment related activities, the real estate sector is also useful for speculation

${ }^{1}$ First Author and Corresponding Author. Management Study Program, Economic Science Institute of Trisna Negara, Indonesia [Postal Address: JIn. M.P. Bangsa Raja No. 27 Belitang Kab. OKU Timur-Sumatera Selatan, 32382, Indonesia]

Email: purwantoup01@gmail.com

(c) Copyright: The Author(s)

This is an Open Access article distributed under the terms of the Creative Commons Attribution Non-Commercial License (https://creativecommons.org/licenses/by-nc/4.0/) which permits unrestricted non-commercial use, distribution, and reproduction in any medium, provided the original work is properly cited. activities because real estate products have both used value and transfer value. Speculators can buy products from a real estate agency when there are chances for growth and then resell them with higher prices. This often induces the high asset prices thus triggers the economic crisis.

In secondary markets, security based mechanism has been established to support investment activities and funding in property sector. Related loans is one of the common conducts among the real estate companies in the business group. Related loans can take the forms of operating loans, non-operating loans, and other loans in both short and long term. Related transactions conducted in business groups can be explained using the approach of New Institutional Economic (NIE) theory (Coase, 1937; Williamson \& Oliver, 2000). In the micro level, two contradicting hypotheses exist that describe RPT in business groups, namely supporting efficient transactions or what is commonly known as transaction cost theory (Coase, 1937; Williamson \& Oliver, 2000) and supporting opportunist transactions as described in agency theory approach (Jensen \& Meckling, 1976).

Working based on transaction cost theory (Coase, 1937; Williamson \& Oliver, 2000), companies within the business group cooperate to minimize information asymmetry and market uncertainty, as well as to achieve competitive 
advantages. Loan providers have greater information of related borrowers in the business group than unrelated parties and the information can be used to assess risk characteristics of investment projects or force the borrowers to leave any bad investment projects earlier. Related parties can make related loans because of the close relationship between the loan provider and the borrower in improving efficiency. Credit monitoring by internal parties can minimize asymmetry risks compared to when extending loans to external parties ( $\mathrm{La}$ Porta et al., 1999). For example, when external capital market is not developing well, internal capital market (like that via related loan) within business groups can be an alternative to funding sources (Khanna \& Palepu, 1999). Some underlying reasons for a company to prefer taking out related loan to third party loans are as follows: quicker cashout process, simpler procedures, familiarity between loan provider and borrower (minimizing information asymmetry), mutualistic relationship (e.g. marketing), and financial pressure (declining profits in several years, limited pledged assets, preventing bankruptcy). These benefits potentially often make related loan impact upon company's efficiency.

In addition, as it is based on agency theory (Jensen \& Meckling, 1976), related loans, apart from providing benefit advantages, is used as a transaction to benefit one particular party (majority stockholders) while the minority stockholders are at risk. The loans to related parties refer to loans provided by fund providers (controlled companies) for those who manage or own a company, or owned and managed by the same person (Jiang et al., 2010). The study (La Porta, Lopezde-Silanes, Shleifer, et al., 2000) used the data of related loans in Mexico and found that loan accounts to related parties reached $20 \%$ of all commercial loans. Besides, loans to related parties are still within proper market conditions. For example, the average of real loan interest rate to related parties is $4 \%$ per year lower than the proper market condition transaction. Related loans used to benefit certain groups can induce inefficient transaction. Studies in companies listed on the Indonesian capital market (Candra Sari \& Baridwan, 2014), receivables to related parties negatively affect the company's profit margin in Indonesian stock exchange market.

The roles of related loans become more important when needed to improve the understanding towards risk potentials in the market structure of real estate around Asia and other countries (Zhu, 2006). The present study aims to evaluate the effects of related loan on a company's performance. The evaluation of related lending and related loan towards performance is useful to investigate if the related loan is advantageous or disadvantageous to the performance. The two studies are aimed to assess the factor of ownership concentration in moderating effects of related loan to company's performance. The effects of ownership concentration towards RPT and the performance have been investigated in the previous studies, nevertheless, there is only limited literature available evaluating the moderating effect of ownership concentration in strengthening or weakening RPT's effect upon performance.

\section{Literature Review}

Related party transaction in business group has two contradicting hypotheses, namely as an opportunist transaction and as an efficient.

\subsection{Related Loans as an Efficient Transactions}

Many companies around the world establish business groups through ownership relationship (Kim \& Cho, 2020; Yim, 2020). Companies involved in the business groups cooperate with each other to improve competitiveness, deal with market uncertainty, and minimize transaction costs (Coase, 1937; Williamson \& Oliver, 2000). Uncertainty occurs in market, competition, technology, and human resources. Internal cooperation between companies starts when the coordination costs for internal companies are lower than the price mechanism in the market. This theory can be extended to the context of business groups. Business groups can reduce market imperfection by minimizing transaction cost (Gordon et al., 2004; Ryngaert \& Thomas, 2007). Forming business groups can help improve efficiency and communication, identify and manage competition, establish long term business relationship, minimize environment uncertainty (Cook, 1977), and upgrading market power. In regards to funding activities, the presence of internal capital market within groups can cause increase in availability of financial resources and more optimal investment allocation due to the minimum information asymmetry. Besides, intragroup security and group reputation effect can increase external access to funding, and group members can get involved in risk sharing and in initiatives to reduce uncertainty risks.

Study in Taiwan found that transactions with related parties have a significant positive effect on efficiency (Wang et al., 2019), especially in the supply chain in the same industry, improves company performance (Wang et al., 2019). The RPT is more likely to be driven by transaction cost issues than by private opportunities issues. Study in India through an event approach found evidence of propping in business groups in India (Maheshwari \& Gupta, 2019). The results of the study found that earnings announcements have a positive effect on the financial health of other companies in the business group. The average of cumulative abnormal return (CAR) of shares from other companies in the business group has a strong and positive relationship with companies that announce earnings. 
It is known from the aforementioned description that internal capital market can improve efficiency and performance by reducing information asymmetry and enriching resource allocation, transaction cost efficiency, therefore transactions among members within the business group can benefit several advantages which can enhance the company's efficiency and performance. The companies among the business group frequently offer facilities for operating and non-operating loans, instead, the companies will reduce market uncertainty, establish long term business relationship, and enhance the market power. This could cause related loans improve asset management efficiency which is measured by the sales ratio of the total asset. The next hypothesis can be formulated as follows.

\section{$\boldsymbol{H}_{1}$ : Related Lending have positive effects on asset} utilization efficiency

\subsection{Related Loans as an Opportunist Transaction}

Agency Theory Approach. There are two agency related problems. First, an agency conflict that arises from the conflict of principal-agency (Agency Problem I). Secondly, an agency conflict that comes from the conflict of interest between principal and principal (Agency Problem II) (Villalonga \& Amit, 2006). Agency Problem I raises due to mismatches of "economic interest" that are induced or that induce information asymmetry (information gaps) between stockholders and the organization. Agency theory assumes that all individuals act of their own accord. The stockholders as the principal are assumed to merely have the interest in increased financial turnout or their own investment to the company. On the other hand, the agency is assumed to accept satisfaction in the form of financial compensation and conditions that follow such relationship (Aggarwal \& Samwick, 2006). One of the hypotheses in this theory is that management in organizing a company tends to overprioritize its own interest to improving the company's value.

Agency Problem II, the majority stockholders with the minority ones, can occur due to transfer activities of resources between companies which are mostly capable of putting the minority stockholders at financial loss. Agency cost which is the inherent cost related to the use of agency due to Agency Problem II (between principal and principal) increases as a result of the tendency of the majority stockholders to take over benefits from the minority stockholders one as well as give out impacts upon the company's performances (Fama \& Jensen, 1983; Young et al., 2008).

Based on the Agency Theory (Jensen \& Meckling, 1976), related loan is possibly used by the majority stockholders to damage the interest of the minority stockholders. The loans to related parties are an important vehicle to transfer cashflow to company groups which are potentially damaging the minority stockholders (La Porta, Lopez-de-Silanes, \& Shleifer, 2000). Related loans in US business groups AS (Shin \& Stulz, 1998) or Kereitsu Japan (Hoshi et al., 1991) have been frequently used as a tunneling facility by controlling stockholders. Major stockholders not only transfer wealth through various related party transactions, like purchases, loan collateral and asset support, but also use the registered companies through sales, illegal collateral and fund appropriation (Peng et al., 2011). In accordance with the above description, the positive effects of related loans towards profitability imply that companies can benefit the tariff of related loans which is lower than the market price.

\section{$\boldsymbol{H}_{2}$ : Related Loans have positive effects on firm profitability}

\subsection{Ownership Concentration in Moderating Effects of Related Loans to Company's Performance}

According to Agency Theory, agency cost comes from two types of conflicts of principal-agency (Agency Problem I) and principal-principal (Agency Problem II) (Villalonga \& Amit, 2006). Seen from the agency problem perspective, ownership concentration of higher companies provides advantages for controlling management and minimizing agency problem I (Bertrand et al., 2002; Villalonga \& Amit, 2006). Higher ownership concentration is a mechanism of corporate governance to observe an agency to be more effective (Anderson et al., 2003; Mazumder, 2017; Sheikh et al., 2019). To companies that are involved in a business group, higher ownership concentration can be useful for them, like in the management control of the company group (Guillén, 2000). Fundamentally, a business group establishes internal transaction market in which resource allocation is organized in groups. Other members of the group can contribute to give useful information, access to funding and technology, and important social interactions (Khanna \& Yafeh, 2007; van Essen et al., 2010) Should a company have adverse performance, other company members may come to save and support by offering assets like fund and skills (Estrin et al., 2009; Gedajlovic \& Shapiro, 2002; Hoskisson et al., 2004).

Such agency related issues are possible to get worse in developing countries due to their under developed institutions and regulations as well as less effective market control (Y. Jiang \& Peng, 2011; Modugu \& Dempere, 2020). Related to the agency problem II, the conflict of principal-principal is that between the controlling stockholders and the minority ones tends to get worse on the owned companies due to the lack of monitoring institutions (Young et al., 2008). On the other hand, when companies are operating in an advanced 
institutional environment, institutions and legal regulations restrict the tendency of the majority stockholders to take over the benefits of the minority ones, which would then cause significant problem in Agency Problem II. Ownership concentration may not significantly enhance the company's performance in the advanced institutional environment because the companies are able to rely on the external markets to vital resources and skills (Jiang \& Peng, 2011). The high control can offer benefits like control mechanism to management against internal transaction markets in which resource allocation is organized in groups (Jiang \& Peng, 2011). With the description above, the ownership concentration should give incentives to strengthen the decision to give the related loans which can affect the company's performance thus the following hypotheses could be formulated.

$\boldsymbol{H}_{3}$ : Ownership Concentration have Moderating Effects of Related Loans on Company's Performance.

\section{Research Methods and Materials}

\subsection{Measurement for Efficient Transaction and Opportunist Transaction}

The literature related with "theory of the firm," like that of Adam Smith and Alfred Marshall suggest that economic actors maximizes profits. The company is the "black box" which operates resources (input) to obtain certain outputs, therefore the economic actors can maximize profits. Theoretically, (on the Production Theory) loans (apart from capital) as funding sources (capital) can affect sales and indirectly impact upon profits. Loans can negatively impact upon net profit as a means of tax economization. In spite of this, related loan ratio of the total loan should be randomized or has not any effect on sales or profits. Positive effects of loans to net profits indicate the benefits of related loans that can be induced by economizing administration cost or cutting down tariff to be lower than the market tariff (interest).

Observed from the fund providers, the increase of loans along with the decline of net profits imply that the below market tariff (interest) of the related loans. Yet, such increase of related loans which entails sales indicate mutualistic benefits from the loans. The fund providers will experience decline of net profit from the cash fund, but the greater amount of related loans may indicate looseness of payment which may affect the market later. Unless it is entailed with significant effects on net profits, there may be an indication of proper tariff against the market interest.

Issues of inefficiency essentially emerges from the assumption that economic actors tend to maximize their profits (Edward et al., 2006). Inefficiency is interpreted as a point or stage of which the objectives of the economic actors are not yet optimized. The chances of not achieving their maximum objective is a common issue among actors. In organizing the business, a company manager likely to deviate from the objectives which may result in consequences like inefficiency (Jensen \& Meckling, 1976).

When a small company grows big and sells its share ownership, agency problem II between majority and minority owners may take place. It is caused by conflict of interest to maximize benefits by managers who agree on the same interest with the majority owners. In companies with concentrated structure of ownership, the interest of manager can be in line with that of the company controlling owner, but may contradict the interest of the minority owner, which can result in inefficiency. Inefficiency of agency issue in the form of investment options are not efficient and the cost paid by the manager is not efficient, that can be measured using inefficient assets (due to adverse investment), overly high production cost and managerial facilities (causing high cost) and business management that causes decline in revenues and profits (Tirole, 1986). The emergence of agency problems can induce nonoptimal, inefficient profits (Jensen \& Meckling, 1976).

The use of sales ratio against the total asset was first used in the study (Ang et al., 2000; Singh \& Davidson, 2003) which took place in America. Both studies use sales ratio against the total asset to measure efficiency of the management in using the company assets to yield sales. Such ratio measures how effective the company management allocates its assets. High sales ratio against the total asset implies that the sales is significant, on the one hand, the low sales ratio indicates that the management has implemented policies like adverse investment or has overpurchased assets. This method, however, has several drawbacks. First, sales may not be always identical with wealth of the stockholders because sales are not always yielded from advantageous activities. Secondly, sales can give cash flow that is taken over by the management and not distributed to stockholders.

In doing transactions with related parties or those with privileged relationship, a company should implement arm's length principle. In the arm's length principle determining prices and transaction profits must be equal and rateable between the transaction of parties with privileged relationship and those not affected with such relationship. To be equal and rateable does not mean to be exactly the same, but proper range of constraints should exist.

\subsection{Data and Analysis}

The present investigation uses secondary data from company financial reports, summary of financial report in Indonesia Capital Market Directory (ICMD), data of company group structures included in the company annual report and company prospectus report. The samples are taken from 35 real estate companies that have complete data and have been registered consistently in Indonesian capital market for the period of 2007-2012, therefore the observation samples total 210 observation data (see Table 1). 
Table 1: Variable and Measurement

\begin{tabular}{|c|c|}
\hline Variable & Measurement \\
\hline Asset Turn Over ratio (ATR) & $\frac{\text { Net Sales }}{\text { Total Asset }}$ \\
\hline ROA & $\begin{array}{l}\text { Net Profit After Tax } \\
\text { Total assets }\end{array}$ \\
\hline Related Party Transaction (RPT) & $\frac{\text { Related Lending- Related Loan }}{\text { Total Asset }}$ \\
\hline Related Lending (RLEND) & $\frac{\text { Related Lending }}{\text { Total Lending }}$ \\
\hline Related Loan (RLOAN) & $\frac{\text { Related Loan }}{\text { Total Loan }}$ \\
\hline Ownership concentration (OWNER) & $\begin{array}{c}\text { Right cash flow }(\mathrm{CFR})=\text { Right control right }+ \text { Indirect rights control } \\
\text { Direct control rights = Percentage of ownership on their own behalf } \\
\text { Indirect control rights = Multiplication \% of ownership in each chain of ownership }\end{array}$ \\
\hline Size & Size $=$ logaritma of Net Sales \\
\hline Debt Equity Ratio (DER) & $\frac{\text { Total liabilities }}{\text { Total Equity }}$ \\
\hline Economic Crisis (DCRISIS) & $\begin{array}{c}\text { Dummy }(1=\text { global financial crisis of } 2008 \text { and } 2009,0=\text { period before crisis period } \\
(2007) \text { and after crisis period }(2010-2012) \text { is called normal period })\end{array}$ \\
\hline
\end{tabular}

Related loans are reviewed from the related lending and related loans. Related lending is measured with related lending on total lending ratio. Related loan is measured by the related loan on total loans ratio. The independent variables consist of Related Lending (RLEND), Related Loan (RLOAN), ownership concentration (OWNER) and moderation variables which are multiplication of ownership concentration with related loan (OWNER * RPT). Control variables are firm size (SIZE) (Kim \& Cho, 2020), and Debt Equity ratio (DER). The method of analysis in this research use model of panel data regression analysis with equation as follows:

$$
\begin{aligned}
A T R=\beta_{0} & +\beta_{1} R L E N D+\beta_{2} R L O A N+\beta_{5} O W N E R \\
& +\beta_{6} O W N E R * R P T+\beta_{7} S I Z E+\beta_{8} D E R+\varepsilon_{1} \\
R O E=\gamma_{0} & +\gamma_{1} R L E N D+\gamma_{2} R L O A N+\gamma_{5} O W N E R \\
& +\gamma_{6} O W N E R * R P T+\gamma_{7} S I Z E+\gamma_{8} D E R+\varepsilon_{2}
\end{aligned}
$$

where: $\beta, \gamma=$ intercept and slope, $\varepsilon=$ error. To assess the accuracy of the sample regression function in assessing the actual value can be measured from its goodness of fit. Statistically the goodness of fit can be measured from the statistical value of $\mathrm{F}$ and coefficient determination. The coefficient of determination $\left(\mathrm{R}^{2}\right)$ is used to determine the percentage of dependent variable change caused by the independent variable. $\mathrm{F}$ test is the significance testing of the equations used to determine how the independent variables influence the dependent variable. The $p$-value is the probability of rejecting the null hypothesis given that it is true. The significance level $(\rho)$ is $1 \%$ (very significant), $5 \%$ (significant) and 10\% (moderate significant). The p-value is less than the significance level, then an investigator may conclude that the observed effect actually reflects the characteristics of the population rather than just sampling error (Cowles \& Davis, 1982).

\section{Results and Discussion}

During 2007-2012, the mean of capability of the real estate companies in yielding revenues is $18.28 \%$ of the total assets, while the mean of capability of real estate companies in yielding net profits is $1,29 \%$ of the total assets. The minimum ROA value is $-6.79 \%$ or in other words, the company is at a loss, while the maximum ROA value is $11.78 \%$. The mean of related lending of the real estate companies is $41.28 \%$ of the total assets. The minimum related lending of the real estate companies is $0 \%$, meaning that there is not any activity of related lending, meanwhile the maximum is at $59.87 \%$ of the total assets (see Table 2). 
Table 2: Description of Variable

\begin{tabular}{|l|c|c|c|c|}
\hline Variable & Mean & STDEV & Minimum & Maximum \\
\hline ATR & 18.28 & 10.69 & 1.65 & 46.43 \\
\hline ROA & 1.29 & 3.44 & -6.79 & 11.78 \\
\hline ROE & 2.28 & 6.26 & -12.95 & 22.07 \\
\hline CFR & 43.39 & 21.90 & 9.05 & 92.88 \\
\hline RLEND & 41.28 & 110.07 & 0.00 & 59.87 \\
\hline RLOAN & 7.44 & 23.18 & 0.00 & 12.79 \\
\hline RPT & -0.30 & 8.72 & -35.30 & 2.16 \\
\hline
\end{tabular}

The average of the related loan of real estate companies is $7.44 \%$ of the total loan. The minimum related loan of the real estate companies is $0 \%$, which means no activity of company's related loans, while the maximum is $12.79 \%$ of the total loans. The mean of related lending of the real estate companies is greater than that of the related loan, because most big companies which have been listed in Indonesia stock exchange are the big companies taking the highest part of the pyramid structure which already have subsidiary companies, listed and not listed. These companies have better resources of fund providers compared to companies included in the lower part of the structure. The mean of the sampled company ownership concentration is $43,39 \%$, indicating the concentrated ownership. The ownership is concentrated when the main stockholder achieves $20 \%$ (Faccio \& Lang, 2002), 50\% (Ang et al., 2000), 10\% (Claessens et al., 2002; La Porta, Lopez-de-Silanes, \& Shleifer, 2000). The highest ownership concentration is $92,88 \%$ indicating concentrated ownership, while the lowest is at $9,05 \%$ which means that the ownership is distributed. The high ownership concentration is useful to keep control of the company.

Based on Figure 1, the development of ROA goes along with the increase of related loan, while ATR develops along with the related lending. The global financial crisis in 2008 has caused an increase in the use of related loan against the total loans, at the same time the average of ROA experienced decline. During the critical condition, the internal capital market reduces the uncertainty risks (see Figure 1).

Generally, the result of the study (Table 3) shows that Related Lending (RLEND) makes a positive impact on Asset utilization ratio (ATR), while the related loan (RLOAN) makes a positive impact on ROA. The ownership concentration (OWNER) directly affects ATR, but does not play the role of moderating variable which strengthens the effects of related lending towards ATR. Ownership concentration (OWNER) shows direct impacts on ROA and as a moderating variable which empowers the effects brought along by related loan on ROA (see Table 3 ).

The companies which are selected to be the object of the present study are real estate companies involved in the business groups and have been positioned in the top part of the pyramid structure. These companies generally have conducted related loan activities, as well as received lending from the related party that are involved in the lower part of the structure. At the time of giving related lending, there is not any increase or decline of profits or loss as the result of giving out the related lending ( $\rho=0,631>5 \%$ ), but the proportion of the related lending is greater and followed by increase in sales $(\rho=0,027<5 \%)$. Related lending does not significantly makes an impact on ROA, meaning that no significant benefit yielded by related lending on administration cost and interest revenue. It implies that related lending is only utilized to manage the market uncertainty (support efficient transaction) compared to the opportunist transaction which affects profits. The regression coefficient value $(\beta)$ is 0,001 , which means the increase (decline) of related lending by $1 \%$ will be followed by the decline of ATR by $0,001 \%$ provided that other variables are constant. The fact that the related lending does not affect the profitability indicates that it is still in the proper tariff (interest) compared to the market interest, thus it does not harm the lender companies. Moreover, related lending shows significantly positive impact on sales ratio, meaning that the lender during the conduct of related lending receives fees like in the form of looseness for payment (related business lending), non-operating related lending, but can still benefit from the sales increase. This finding indicates benefits of related loan to market performance that supports the hypothesis of efficient transaction. Related lending with lower interest than the market price will put the minority stockholders at a loss, and it is not done to maintain the market confidence. 


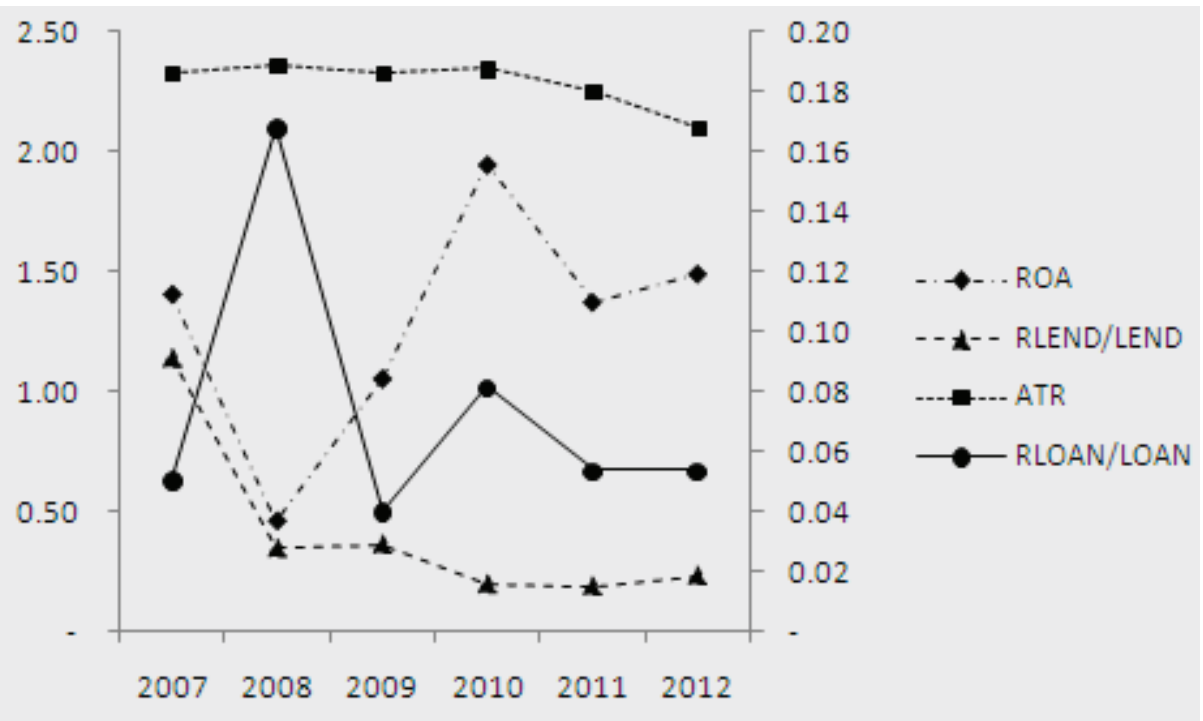

Figure 1: Correlation of Loans and Corporate Performance Sector Loans in Real Estate Firms 2007-2012 Source: processed from Indonesia Capital Market Directory (ICMD) 2007-2012

Table 3: Regression Test Summary

\begin{tabular}{|l|c|c|c|c|}
\hline \multirow{2}{*}{} & \multicolumn{2}{|c|}{ ATR } & \multicolumn{2}{c|}{ ROA } \\
\cline { 2 - 5 } & $\boldsymbol{\beta}$ & $p$ & $\boldsymbol{\beta}$ & $p$ \\
\hline Constant & 0.132 & 0.119 & -13.954 & 0.000 \\
\hline RLEND & 0.001 & 0.027 & -0.004 & 0.631 \\
\hline RLOAN & 0.018 & 0.579 & 3.564 & 0.001 \\
\hline OWNER & 0.001 & 0.000 & 0.035 & 0.002 \\
\hline OWNER*RPT & 0.001 & 0.410 & 0.108 & 0.012 \\
\hline SIZE & -0.002 & 0.782 & 0.980 & 0.000 \\
\hline DER & 0.019 & 0.052 & -0.484 & 0.110 \\
\hline & & & & \\
\hline R-squared & 0.130 & & 0.194 & \\
\hline Adjusted R-squared & 0.081 & & 0.149 & \\
\hline F-statistic & 2.671 & & 4.316 & \\
\hline Prob(F-statistic) & 0.003 & & 0.000 & \\
\hline Durbin-Watson stat & & & & \\
\hline Jarque-Bera (p) & & & & \\
\hline Breusch-Godfrey Serial Correlation LM Test $(\mathrm{p})$ & & & & \\
\hline Heteroskedasticity Test: Breusch-Pagan-Godfrey (p) & & & & \\
\hline
\end{tabular}

Note: ${ }^{* * *}$ ) level of significancy $=1 \%,{ }^{* *}$ ) level of significancy $=5 \%,{ }^{*}$ ) level of significancy $=10 \%$

Source: processed from Indonesia Capital Market Directory (ICMD) 2007-2012 
The companies involved in the business group cooperate to improve the market uncertainty and enhance the competence. Related loan minimizes the risks due to the familiarity between the fund provider and the receiver. Resource transfer between companies within the same business group is one of the group policies of extending advantages in the form of support (mutualistic business) between companies in the business group (Gopalan et al., 2007; Ying \& Wang, 2013). Partners can offer strategic alliance using resources like products, distribution line, manufacturing capability, project funding, capital equipment, knowledge, expertise, or intellectual property. Alliance is cooperation or collaboration aiming to synergize in which partners expect to receive greater benefits from it than those possibly received from individual attempts. Frequently, alliance involves technology transfer (access to knowledge and expertise), economic specialization, mutual costs and risks.

Relatedloan positively impacts upon $\operatorname{ROA}(\rho=0,001<5 \%)$, but does not impact significantly on ATR $(\rho=0,579>5 \%)$. The greater the proportion of the related loan against the total loan along with the increased ROA, the greater the proportion of the total loan with the increase in profits but not in sales. This finding indicates the benefit of taking out the related loan towards the administration cost and interest revenue. In other words, related loan is in support of the opportunist transaction which affects profits. The regression coefficient value $(\beta)$ is 3,564 , meaning that the increase (decline) of related loan by $1 \%$ will be followed by the increase (decline) of ROA by $3,564 \%$, provided that other variables are constant.

That related loan is positive and significant on the profitability ratio indicates related loan is done in tariff lower than the market interest, thus the receiver of the loan is benefited while the lender is at a loss. This finding is in support of the opportunist transaction, not the efficient one. Related loan in business group has the potential to be utilized by the controlling stockholders to transfer company resources in the group to intentionally yield benefits the majority stockholders. The current asset is transferred to the controlling stockholder using related lending via related loan. The tunneling potential in the related lending transaction conducted in business group occasionally involves parties other than the financial institutions like banks, rather involves the non-bank financial institutions or non-financial companies. It happens due to the fact that related lending transaction inside the business group is not regulated as strict as it is with banking, or because the media and investors' attention is not much reported. Whereas, such cases happen a lot (minority investors are suspicious about their rights being unprotected), which in the longer term can damage the reputation of the capital market. The limitation of civil law in Indonesia makes an impact on the security quality over minority stockholders, resulting in tunneling activities. A country with quality security to minority stockholders usually has more companies with concentrated ownership structure with the pyramid system.

The ownership concentration has shown a direct, positive attitude towards ATR $(\rho=0,036<5 \%)$ and ROA $(\rho=0,036$ $<5 \%$ ). The regression coefficient value $(\beta)$ of the effects of ownership concentration on ATR is 0,001 that means the increase (decline) of the ownership concentration by $1 \%$ will be followed along with the increase (decline) of Asset Turnover Ratio by $0,001 \%$, provided that other variables are constant. The regression coefficient $(\beta)$ of the effects of ownership concentration on ROA by 0,001 implies that the increase (decline) of ownership concentration by $1 \%$ will entail the increase (decline) of ROA by $0,001 \%$, provided that other variables are constant.

The ownership concentration has been found to strengthen the effects of related loan towards $\operatorname{ROA}(\rho=0,036$ $<5 \%$ ), but not moderate the effects of related lending to ATR $(p=0,036<5 \%)$ and $\operatorname{ROA}(\rho=0,036<5 \%)$. The regression coefficient $(\beta)$ of ownership concentration in moderating the effects of related loan towards ROA by 0,001 indicates that the increase (decline) of the multiplication of ownership concentration and related loan is $1 \%$ and will be followed by the increase (decline) of ROA by $0,001 \%$, provided that other variables are constant. The higher concentration of corporate ownership provides an advantage for controlling management and minimizing agency problems I. On the other hand, high ownership tends to encourage opportunism and a decline in company performance (Li et al., 2008), especially in weak governance in developing countries (Modugu \& Dempere, 2020). The minority stockholders with minimum shares $(<5 \%)$ can easily sell their shares should they observe any opportunist activities exist which would later put them at loss.

\section{Conclusions}

The result of the present study shows that related lending positively makes an impact on sales but not on profits which would go for the efficient transaction, while related loan positively impacts on profits and supports the opportunist transaction. Concentration of ownership moderates the effects of related loan on the company's performance. Generally, the findings that related lending is utilized for mutual activities between companies within the business group of real estate sector in Indonesia, while related lending is also open for being used in tunneling activities. The results of this study have implications for emphasizing the importance of governance to increase the benefits of related loans. 
This study has several limitations. First, this study focuses on testing the benefits-risks of related party transactions in conditions of uncertainty (crisis). This study does not involve governance aspects. Therefore, this study recommends future research to analyze governance factors. Second, this study focuses on related lending and related loans in business groups. However, there are still other types of related party transactions to explore, such as transfer pricing, asset sales and purchases, loan guarantees, and equity-based incentive compensation. Therefore, this study recommends future research to further explore these other types of transactions.

\section{References}

Aggarwal, R. K., \& Samwick, A. A. (2006). Empire-builders and shirkers: Investment, firm performance, and managerial incentives. Journal of Corporate Finance, 12(3), 489-515. https://doi.org/10.1016/j.jcorpfin.2006.01.001

Anderson, R. C., Mansi, S. A., \& Reeb, D. M. (2003). Founding family ownership and the agency cost of debt. Journal of Financial Economics, 68(2), 263-285. https://doi.org/10.1016/ S0304-405X(03)00067-9

Ang, J. S., Cole, R. A., \& Lin, J. W. (2000). Agency costs and ownership structure. Journal of Finance, 55, 81-106. https:// doi.org/10.1111/0022-1082.00201

Bertrand, M., Mehta, P., \& Mullainathan, S. (2002). Ferreting out Tunnelling: An application to Indian business groups. Quarterly Journal of Economics, 117, 121-148. https://doi. org/10.3386/w7952

Candra Sari, R., \& Baridwan, Z. (2014). Current Asset Tunneling and Firm Performance in an Emerging Market. Indonesian Journal of Accounting and Finance, 11(2), 165-176. https:// doi.org/10.21002/jaki.2014.09

Claessens, S., Djankov, S., Fan, P. H., \& Lang, H. P. (2002). Disentangling the incentive and entrenchment effects of large shareholdings. Journal of Finance, 62(6), 2741-2771. https:// doi.org/10.1111/1540-6261.00511

Coase, R. H. (1937). The Nature of the Firm. Economica, New Series, 4(16), 386-405. https://doi.org/10.1111/j.1468-0335.1937. tb00002.x

Cook, K. S. (1977). Exchange and power in networks of interorganizational relations. The Sociological Quarterly, 18, 62-82. https://doi.org/10.1111/j.1533-8525.1977.tb02162.x

Cowles, M., \& Davis, C. (1982). On the Origins of the .05 Level of Statistical Significance. American Psychologist, 37, 553-558. https://doi.org/10.1037/0003-066X.37.5.553

Edward, S., Allen, A. J., \& Shaik, S. (2006). Market Structure Conduct Performance (SCP) Hypothesis Revisited Using Stocastic Frontier Efficiency Analysis. Agribusiness \& Applied Economics, 649, 1-19. https://doi.org/10.22004/ag.econ.21350

Estrin, S., Poukliakova, S., \& Shapiro, D. (2009). The performance effects of business groups in Russia. Journal of Management
Studies, 46, 393-420. https://doi.org/10.1111/j.14676486.2008.00820.x

Faccio, M., \& Lang, L. H. P. (2002). The ultimate ownership of Western European corporations. Journal of Financial Economics, 65(3), 365-395. https://doi.org/10.1016/S0304405X(02)00146-0

Fama, E. F., \& Jensen, M. C. (1983). Separation of ownership and control. Journal of Law and Economics, 26, 327-349. https:// doi.org/10.1086/467037

Gedajlovic, E., \& Shapiro, D. M. (2002). Empirical Evidence on Ownership Structure, Management Control and Agency Costs. Ownership Structure and Firm Profitability in Japan. https:// doi.org/10.2139/ssrn.1343880

Gopalan, R., Nanda, V., \& Seru, A. (2007). Affiliated Firms And Financial Support: Evidence From Indian Business Groups. Journal of Financial Economics, 86(3), 759-795. https://doi. org/10.1016/j.jfineco.2006.09.008

Gordon, E. A., Henry, E., \& Palia, D. (2004a). Related party transactions: Associations with corporate governance and firm value. SSRN ELibrary. https://doi.org/10.2139/ssrn.558983

Gordon, E. A., Henry, E., \& Palia, D. (2004b). Related party transactions and corporate governance. Advances in Financial Economics, 9, 1-27. https://doi.org/10.1016/S15693732(04)09001-2

Guillén, M. F. (2000). Business groups in emerging economies: A resource-based view. Academy of Management Journal, 43(3), 362-380. https://doi.org/10.5465/1556400

Hoshi, T., Kashyap, A., \& Scharfstein, D. (1991). Corporate Structure, Liquidity, and Investment: Evidence from Japanese Industrial Groups. Quarterly Journal of Economics, 106, 33-60. http://hdl.handle.net/10.2307/2937905

Hoskisson, R. E., Cannella, A. A., Tihanyi, L., \& Faraci, R. (2004). Asset restructuring and business group affiliation in French civil law countries. Strategic Management Journal, 25, 525-539. https://doi.org/10.1002/smj.394

Jensen, M. C., \& Meckling, W. H. (1976). Theory of the Firm: Managerial Behavior, Agency Costs and Ownership Structure. Journal of Financial Economics, 3(4), 305-360. https://doi. org/10.1016/0304-405X(76)90026-X

Jiang, G., Lee, C. M. C., \& Yue, H. (2010). Tunneling through intercorporate loans: The China experience. Journal of Financial Economics, 98(1), 1-20. https://doi.org/10.2139/ ssrn. 1154314

Jiang, Y., \& Peng, M. W. (2011). Principal-principal conflicts during crisis. Asia Pacific Journal of Management, 28(4), 683695. https://doi.org/10.1007/s10490-009-9186-8

Khanna, T., \& Palepu, K. (1999). Emerging Market Business Group, Foreign Investor, and Corporate Governance. https:// doi.org/10.3386/w6955

Khanna, T., \& Yafeh, Y. (2007). Business groups in emerging markets: Paragons or parasites? Journal of Economic Literature, 45, 331-372. https://doi.org/10.1257/jel.45.2.331 
Kim, H. S., \& Cho, K.-S. (2020). The Determinants of Blockholder Presence: Evidence from Korea. Journal of Asian Finance, Economics and Business, 7(4), 29-39. https://doi.org/10.13106/ jafeb.2020.vol7.no4.29

La Porta, R., Lopez-de-Silanes, F., \& Shleifer, A. (1999). Corporate Ownership Around The World. Journal of Finance, 54(2), 471517. https://doi.org/10.1111/0022-1082.00115

La Porta, R., Lopez-de-Silanes, F., \& Shleifer, A. (2000). Tunneling. American Economic Review, 90, 22-27. https://doi. org/10.1257/aer.90.2.22

La Porta, R., Lopez-de-Silanes, F., Shleifer, A., \& Vishny, R. W. (2000). Investor Protection and Corporate Governance. Journal of Financial Economics, 58, 3-27. https://doi.org/10.1016/ S0304-405X(00)00065-9

Li, H. X., Wang, Z. J., \& Deng, X. L. (2008). Ownership, independent directors, agency costs and financial distress: Evidence from Chinese listed companies. Corporate Governance, 8(5), 622636. https://doi.org/doi.org/10.1108/14720700810913287

Maheshwari, Y., \& Gupta, P. (2019). Propping in Business Groups: Prediction Efficacy of Earnings Announcements. Global Business Review, 1-15. https://doi. org/10.1177/0972150919845220

Mazumder, M. M. M. (2017). Top-executives Compensation: The Role of Corporate Ownership Structure in Japan. The Journal of Asian Finance, Economics and Business, 4(3), 35-43.

Modugu, K. P., \& Dempere, J. (2020). Country-Level Governance Quality and Stock Market Performance of GCC Countries. Journal of Asian Finance, Economics and Business, 7(8), 185-195. https://doi.org/10.13106/jafeb.2020.vol7.no8.185

O'Sullivan, A., \& Gibb, K. (2003). Housing Economics and Public Policy. Oxford, UK: Blackwell/RICS.

Peng, W. Q., Wei, K. C. J., \& Yang, Z. (2011). Tunnelling or Propping: Evidence from Connected Transactions in China. Journal of Corporate Finance, 17, 306-325. https://doi. org/10.1016/j.jcorpfin.2010.08.002

Ryngaert, M. D., \& Thomas, S. E. (2007). Related Party Transactions: Their Origins and Wealth Effects. https://doi. org/10.2139/ssrn.970689

Sheikh, M. F., Bhutta, A. I., \& Sultan, J. (2019). CEO Compensation and Unobserved Firm Performance in Pakistan. Journal of Asian Finance, Economics and Business, 6(3), 305-313. https://doi.org/10.13106/jafeb.2019.vol6.no3.305

Shin, H., \& Stulz, R. M. (1998). Are Internal Capital Market Efficient? Quarterly Journal of Economics, 113, 531-552. https://doi.org/10.1162/003355398555676
Singh, M., \& Davidson, W. N. (2003). Agency costs, ownership structure and corporate governance mechanisms. Journal of Banking and Finance, 27, 793-816. https://doi.org/10.1016/ S0378-4266(01)00260-6

Tirole, J. (1986). Procurement and renegotiation. Journal of Political Economy, 84, 4-25. https://doi.org/10.1086/261372

van Essen, M., Carney, M., Gedajlovic, E. R., Heugens, P., \& van Oosterhout, J. (2010). Do US publiclylisted family firms differ? Does it matter? A meta-analysis. https://doi.org/10.2139/ ssrn. 1837517

Villalonga, B., \& Amit, R. (2006). How do family ownership, management, and control affect firm value? Journal of Financial Economics, 80, 385-417. https://doi.org/10.1016/j. jfineco.2004.12.005

Wang, H. D., Chob, C. C., \& Linc, C. J. (2019). Related party transactions, business relatedness, and firm performance. Journal of Business Research, 101, 411-425. https://doi. org/10.1016/j.jbusres.2019.01.066

Wang, W. K., Lu, W. M., Kweh, Q. L., \& Siao, W. Y. (2019). Relatedparty transactions and corporate performance following the adoption of International Financial Reporting Standards in Taiwan. Managerial and Decision Economics, 1-9. https://doi. org/10.1002/mde.3106

Williamson, O. E. (2000). The New Institutional Economics: Taking Stock, Looking Ahead. Journal of Institutional and Theoretical Economics, 99-118. https://doi.org/10.1257/jel.38.3.595

Yim, S. G. (2020). Individual Blockholder's Influence on Accounting Quality: Evidence from Korea. Journal of Asian Finance, Economics and Business, 7(1), 59-69. https://doi. org/10.13106/jafeb.2020.vol7.no1.59

Ying, Q., \& Wang, L. (2013). Propping by Controlling Shareholders, Wealth Transfer and Firm Performance: Evidence From Chinese Listed Companies. China Journal of Accounting Research, 6(2), 133-147. https://doi.org/10.1016/j.cjar.2013.02.001

Young, M., Peng, M. W., Ahlstrom, D., Bruton, G., \& Jiang, Y. (2008). Governing the corporation in emerging economies: A review of the principal-principal perspective. Journal of Management Studies, 45, 196-220. https://doi.org/10.1111/ j.1467-6486.2007.00752.x

Zhu, H. (2006). The Structure of Housing Finance Markets And House Prices In Asia. December, 55-69. https://econpapers. repec.org/RePEc:bis:bisqtr:0612g 